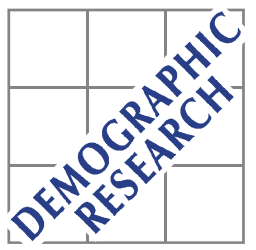

Demographic Research a free, expedited, online journal of peer-reviewed research and commentary in the population sciences published by the Max Planck Institute for Demographic Research Konrad-Zuse Str. 1, D-18057 Rostock · GERMANY www.demographic-research.org

DEMOGRAPHIC RESEARCH

VOLUME 26, ARTICLE 2, PAGES 41-62

PUBLISHED 26 JANUARY 2012

http://www.demographic-research.org/Volumes/Vol26/2/

DOI: $10.4054 /$ DemRes.2012.26.2

Research Article

Whose job instability affects the likelihood of becoming a parent in Italy?

A tale of two partners

Daniele Vignoli

Sven Drefahl

Gustavo De Santis

(C) 2012 Daniele Vignoli, Sven Drefahl \& Gustavo De Santis.

This open-access work is published under the terms of the Creative Commons Attribution NonCommercial License 2.0 Germany, which permits use, reproduction \& distribution in any medium for non-commercial purposes, provided the original author(s) and source are given credit. See http:// creativecommons.org/licenses/by-nc/2.0/de/ 


\section{Table of Contents}

1 Introduction $\quad 42$

2 Fertility, couples, and economic uncertainty: Literature review 44

$2.1 \quad$ Couples, employment, and fertility 44

2.2 Economic uncertainty, gender, and fertility 45

$3 \quad$ Italy: The background 46

3.1 Paid work and family life in times of increasing economic
uncertainty

3.2 Work and the first child in Italy from a gender perspective:
Previous findings

$4 \quad$ Analytical strategy $\quad 48$

$\begin{array}{llr}5 & \text { Results } & 50\end{array}$

6 Conclusions $\quad 53$

$\begin{array}{llr}7 & \text { Acknowledgements } & 54\end{array}$

References $\quad 55$

$\begin{array}{ll}\text { Appendix } & 61\end{array}$ 


\title{
Whose job instability affects the likelihood of becoming a parent in Italy? A tale of two partners
}

\author{
Daniele Vignoli ${ }^{1}$ \\ Sven Drefahl ${ }^{2}$ \\ Gustavo De Santis ${ }^{3}$
}

\begin{abstract}
We examine the likelihood of becoming a parent in Italy taking into account the employment (in)stability of both partners in a couple. We use data from four waves of the Italian section of the EU-SILC (Statistics on Income and Living Condition), 20042007, accounting for its longitudinal nature. Overall, our results suggest that Italian couples are neither fully traditional nor entirely modern: the "first pillar" (i.e., a male partner with a stable and well-paid job) is still crucial in directing fertility decisions, because, in our interpretation, it gives the household a feeling of (relative) economic security. But this "old" family typology is becoming rare. Increasingly, both partners are employed, and in this case the characteristics of their employment prove important. A permanent occupation for both partners is associated with higher fertility, while alternative job typologies for either of the two depress fertility.
\end{abstract}

${ }^{1}$ Department of Statistics, University of Florence. E-mail: vignoli@ds.unifi.it.

${ }^{2}$ Stockholm University Demography Unit. E-mail: sven.drefahl@sociology.su.se.

${ }_{3}^{3}$ Department of Statistics, University of Florence. E-mail: desantis@ds.unifi.it. 


\section{Introduction}

In recent decades, period total fertility has declined in almost all industrialized countries and reached values below (sometimes well below) replacement. The recovery from these values in the past few years, especially in Europe, has generally been moderate. In Italy, for instance, the Total Fertility Rate was 1.4 in 2010, after having reached a minimum of 1.2 in 1995. Formerly, it seemed natural to associate fertility decline with the parallel increase in women's labour force participation. Since the mid-1980s, however, the European countries where women are most active in the labour market are also those where fertility is highest. The macro level association between female labour force participation and fertility has now become positive (Brewster and Rindfuss 2000; Ahn and Mira 2002; Engelhardt, Kögel, and Prskawetz 2004), although at the micro level this is not (yet) the case: a meta-analysis of micro level studies indicates that the relationship between female labour-force participation and fertility remains negative, but the strength of the association is stronger where the male breadwinner model prevails (e.g., Southern Europe), and weaker in the Nordic countries (Matysiak and Vignoli 2008). ${ }^{4}$

Recently, the increasing competition in the labour markets and employers' rising demands for workers' (extended) flexibility have further discouraged childbearing in general (Mills and Blossfeld 2005), in particular the transition to first birth (Kreyenfeld 2010). The anticipated difficulties in finding a job may induce women to postpone childbearing until they have established a relatively solid position in the labour market. The employment instability and job precariousness that characterize contemporary labour markets increase uncertainty and intensify the difficulties experienced by the young in their transition to adulthood, when they start their labour market careers, try to strengthen their economic position and begin to consider family formation (e.g., McDonald 2006; Matysiak and Kotowska 2011). Most studies on the link between economic uncertainty and fertility focus on transition to parenthood (that is, occurrence of first births), because income and job insecurity discourage particularly long term commitments, including family formation (Billari 2005; Salvini and Ferro 2007). Of course, the postponement of childbearing, reinforced by the increasing uncertainty in the labour market, may, in turn, affect completed fertility because of the limited time interval left for second or higher order births. Delaying entry into motherhood may, in some cases, also lead to involuntary childlessness (Ongaro 2002).

At the micro level, the links from economics (income, labour income, and employment conditions) to fertility are complex, especially if considered at the couple, and not just at the individual, level (Oppenheimer 1976). In the interactions and

\footnotetext{
${ }^{4}$ For a similar finding at the macro level, see Kögel $(2004,2006)$.
} 
negotiations between parents to be, gender differences must be explicitly considered, in terms of both labour market participation and contribution to non market activities (Singley and Hynes 2005). In Southern Europe, where women are the main caregivers and men act primarily as household providers, the economic well-being of the household depends mainly on the market performance of the man. When this dwindles, as is more and more frequently the case in contemporary societies, several consequences may ensue, also influencing fertility.

Our study focuses on Italy, a contradictory society, where institutional support for working women has traditionally been modest, part-time work is rare, working schedule rigid, and public childcare provision scarce, especially when the child is very young (Istat 2011). Reforms of the Italian labour market began in the early 1980s, accelerated in the second half of the 1990s ("legge Treu," 1997), and then spiked in the early 2000s ("legge Biagi," 2003). "Flexible" forms of work have now become widespread, and they have led to the creation of about fifty new types of contracts (temporary, part-time, linked to specific projects, etc.), all of them far less "protective" for the worker than former, typically unlimited jobs used to be (Barbieri 2011). These contracts are offered almost exclusively to the young, whose traditionally high unemployment, in the meantime, has not declined significantly (Istat 2011). The traditional division between 'insiders' and 'outsiders' in the labour market has therefore been reinforced: the former are typically male, older workers, with long-term contracts, and solid guarantees in case of unemployment; the latter are young, or women, with precarious occupations, low pay, and very limited (or altogether nonexistent) safety nets for their unemployed periods (Ferrera 1985; 2000; Bettio and Villa, 1998).

Italy constitutes an intriguing case-study also from a gender perspective. Gender inequality in the labour market is pronounced: women's participation, although on the rise, is still relatively low (the occupation rate for the age range 15-64 is about 47\%) and men, especially young men, are today confronted with a worsening of their economic situation due to the increasing diffusion of employment instability (e.g., Salvini and Ferro 2007).

The implications of this are not well understood, yet (Barbieri 2011), and we share Barbieri and Scherer's (2009: 689) opinion that: "Future research will have to place more attention on the social risks attached to the new forms of employment, and their consequences to other spheres of life like family formation." Our paper responds to this call for more research on the link between job instability and family formation in contemporary Italy. We examine first order fertility differentials, considering not only income, but also the degree of job stability of prospective parents, taking into account the economic situation of both partners in a couple. We continue with a literature review of the associations between economic uncertainty, couples' context, and fertility (Section 2) and with a special emphasis on Italy (Section 3). This is followed by a 
description of the study's analytical strategy (Section 4), and a presentation of the results (Section 5). Finally, we summarize and discuss the implication of our main findings (Section 6).

\section{Fertility, couples, and economic uncertainty: Literature review}

\subsection{Couples, employment, and fertility}

The new home economics (Becker 1981) relates recent transformations in the tempo and quantum of family formation in Western countries to the increased human capital and socioeconomic empowerment of women, which makes children more expensive, and induces parents to trade quantity (fewer children) for quality (children with better health, more education, etc.). However, the process is more complex than this. In the first place, the mere postponement of the age when education is completed affects family formation: a process that is common to both genders (Blossfeld 1995). Besides, it may not just be "women's business," as the theory suggests: several changes also affect men's opportunities and role, and gender relations within the couple (Rosina and Sabbadini 2006; Neyer, Lappegård, and Vignoli 2011). Where significant gender differences exist in work and family involvement (especially during the transition to parenthood), couple-level research is therefore warranted (Singley and Hynes 2005). In their meta-analysis of micro level studies on the relationship between female labourforce participation and fertility, for instance, Matysiak and Vignoli (2008) find that, together with indicators of women's job characteristics (working hours, type of contract, and so on), it is also useful to include information about the partner and his occupation. Omitting this dimension leads to an overestimation of the negative effect of women's employment on fertility.

Regarding the impact of the partner's characteristics, however, there is only modest empirical evidence. Specific combinations of the characteristics of both partners in a couple may play an important role in determining reproductive choices (Corijn, Liefbroer, and De Jong Gierveld 1996; Dalla Zuanna 2001; Pinnelli and Di Giulio 2003). In this case, too, the context matters: Baizan (2005) argues that the relationship between fertility and labour market participation of both members of a couple depends on the characteristics of the labour market, the cultural context and the type of welfare state. For instance, the combination "working husband with housewife" has a positive effect on second order births in the United Kingdom and in Italy, but not in Denmark, where gender equity is higher. Mencarini (2006), applying Cox regression to the 1998 "Families and Social Subjects" (FSS) data, analyse the determinants of the risk of having a second child in Italy, focusing on the effects generated of specific 
combinations of male and female work activities. She notes that, within couples, non working women are more likely to have a second child and for both employed and unemployed women fertility is higher in couples where men work in high occupational classes. ${ }^{5}$ These results are in accordance with the micro economic theories that stress the role of the husband's income on the transition to the second child, rather than with those emphasizing the fertility-propelling role of gender symmetry.

\subsection{Economic uncertainty, gender, and fertility}

Unemployment is considered a valid marker of instability over one's employment history (Pailhé and Solaz 2008). Its effect on fertility, however, may differ between men and women. Amongst men, unemployment reduces the risk of couple formation and therefore also parenthood (Ahn and Mira 2002). For women, the influence of (un)employment on first birth timing remains ambiguous (Hoem 2000; Kravdal 2002; for an overview see Sobotka, Skirbekk, and Philipov 2011).

Job stability, too, appears to be an important condition for parenthood, perhaps even more than the transition to employment itself (for an overview see Kreyenfeld 2010). But regular long-term contracts tend to become rarer, especially among young adults, and temporary contracts depress fertility (De la Rica and Iza 2005; Gonzalez and Jurado-Guerrero 2006; Salvini and Ferro 2007). Overall, temporary contracts may inhibit a successful reconciliation between work and family life exacerbating the level of conflict as well as peoples' dissatisfaction and economic pressure (Scherer 2009). Temporary employees report lower levels of life satisfaction and their perceived household income situation is worse (ibid). These new working patterns tend to be gendered: the proportion of temporary workers is higher among women than among men (Drew and Emerek 1998).

Overall, unemployment and temporary (instead of permanent) working contracts create uncertainties that tend to inhibit family formation in contemporary Europe (Kohler and Kohler 2002; Blossfeld et al. 2005; Goldstein, Sobotka, and Jasilioniene 2009; Scherer 2009; Hondroyiannis 2010). What remains unclear is whose employment career these uncertainties refer to (Kreyenfeld and Konietzka 2005): the man's, the woman's, or both? Kreyenfeld (2010) argues that the effect of women's employment on childbearing must be contextualized: "whether a woman whose position in the labour market is insecure will postpone childbirth varies according to whether she is expected to be a caregiver or household provider after childbirth." Women's stable employment may constitute a stronger barrier to childbearing in settings characterized by a pronounced insider-outsider divide, and in countries that lack safety nets and family

${ }^{5}$ As measured in the year following the birth of the first child. 
policies aimed at reconciling motherhood and paid work. On the other hand, research on the potential impact of labour-market conditions on men's fertility normally starts from the (explicit or implicit) assumption that men are the main providers for a family. Oppenheimer $(1988,2003)$ argues that the deterioration of men's position in the labour market and the declining ability of men to serve as the family's single breadwinner are key factors for understanding the recent postponement of marriage and fertility. More so, probably, where the traditional view of the man as the main breadwinner still prevails.

\section{Italy: The background}

\subsection{Paid work and family life in times of increasing economic uncertainty}

Italy has always been characterized by a low participation of women in the labour market. Currently, for instance, the labour force participation rate of women aged 25-44 stands at $67 \%$, which is about ten percentage points below the EU average. As mentioned, work and welfare conditions are favourable only for the so-called "inside" workers, and harsh on the others (Ferrera 1985, 2000). Take unemployment, for example: 'inside' workers have access to an unemployment benefit (the Cassa Integrazione) which may cover up to $90 \%$ of previous net earnings for a few years. When they retire, inside workers get an old age pension that typically replaces about three-quarters of previous labour earnings. Conversely, provisions for 'outside' workers (young, or women, or both) are typically lower and granted only for shorter periods, if at all - and this in a country where no minimum income is guaranteed, except for the old (65 and over). This polarised pattern between over-protected and under-protected categories is well documented also in comparative perspective (Ferrera 1996).

Italy has experienced a strong increase in educational attainment and labour market participation of women in the last decades, but not everything has adjusted to the ongoing societal change: rigid working hours, scarce public services, traditional family structures, and very limited male participation in domestic chores, among other issues, indicate that the old-fashioned notion that mothers, and perhaps women more in general, should be (mainly) housewives is still alive. This state of affairs has long supported the prevalence of the male breadwinner model that maximizes, on the one hand, men's income security and, on the other, women's time availability at home. Although only a few political actions have effectively tackled the conflict between motherhood and work, the dual earner model is becoming more and more widespread, and in some regions of the North it is now competing with the sole male breadwinner model. The contrast generated by women's increasing desire to participate in paid 
employment and the traditional, family-oriented welfare state results in two main consequences. One is lower-than-desired fertility (McDonald 2000; 2002). The other is polarization: indeed, almost all the women who have accumulated some work experience before their first conception re-enter paid work within a year from childbirth. By contrast, women who have never worked before their first conception tend to remain out of the labour market after they become mothers (Matysiak and Vignoli 2010).

In Italy unemployment is high among the young (22\% in 2006; Eurostat New Cronos Database, Labor Force Survey data), and the gender gap is large (Adsera, 2005). Institutional, structural, and cultural lags have made fertility and paid work scarcely compatible: women who plan to be economically active are discouraged from childbearing, which they typically postpone, or forego altogether. The increasing uncertainty and instability of employment contracts has made things worse: Italy is one of the countries with the highest proportion of employees on temporary contracts, exceeding 35\% among those aged $15-24$ years, and 15\% among those aged $25-49$ in 2006 (Eurostat New Cronos Database, Labor Force Survey data).

\subsection{Work and the first child in Italy from a gender perspective: Previous findings}

Little research has focused on how Italian couples arrange their work and family life when they become parents. Rosina and Fraboni (2006), examining data derived from the 1998 ISTAT Multipurpose Survey "Family and Social Subjects" (FSS), find that women who had never worked before marriage have their first child earlier than those with some work experience. Since virtually all men are employed already before marriage, this finding suggests the presence of more traditional behaviours among couples where the gender asymmetry in the labour market prevails. Vignoli and Salvini (2008), in their event-history analysis based on the 2003 FSS data, find high first birth risks among single-earner couples (where the man is permanently employed and the woman does not work), compared to the couples where both partners are permanently employed. Santarelli (2011), with a longitudinal (event-history) analysis based on the European Community Household Panel (ECHP), studies the transition to first child (conception) for childless married couples in the period 1994-2001. She, too, finds that single-earner couples have their first child earlier than dual earner couples, but the type of contract does not seem to matter much, in this respect. Santarelli (2011) also tests the influence of couple's income (broken down by type: from work or social/private transfers) on first birth risks, but without controlling for the couple's employment (in)stability. 
A few other studies on the link between economic uncertainty and fertility in Italy are based on ILFI (Indagine longitudinale sulle famiglie italiane) data, the last wave of which dates back to 2005. Barbieri (2011) claims that women who are permanently employed have the highest first birth hazards. On the contrary, first birth risks are considerably lower for women in atypical employment than for women in any other employment situation; including women working "off-the-book" (i.e., in the underground economy). Barbieri and Bozzon (2009) claim that what is crucial for family formation in Italy is whether a woman can rely on a stable and secure job. From a gender perspective, Mencarini and Solera (2011) confirm that employment instability matters for the likelihood of becoming a parent, but in a gendered way: the man's position in the labour market is more important than the woman's. This is in line with Bernardi and Nazio's (2005) claim that having a good and stable job is more important for the man than for the woman in informing a couple's decision to have a first child.

While the general picture for Italy is thus relatively clear, a few research questions have remained unanswered. What has become of the connection between economic uncertainty and the likelihood of becoming a parent in recent years, especially after the liberalization of the labour market, i.e., after the 2003 Biagi Law? How relevant is the recent increasing uncertainty of the labour market for the decision to become a parent? Does money (that is, labour income) matter more or less than job security? Do men and women behave similarly, and, if not, what are their main differences in this respect?

\section{Analytical strategy}

For our analysis we use four waves of the Italian survey of the EU-SILC (Community Statistics on Income and Living Condition), 2004-2007. The EU-SILC program is the statistical data reference source for comparative statistics on income for the European Union and is conducted in each member state: it collects detailed longitudinal information on the social and economic characteristics of individuals and households. The Italian EU-SILC, launched in 2004, follows the rotational design proposed by Eurostat (European Commission 2010). Each year a new sample is drawn, and it is followed for four years. Each sample is representative of the whole Italian population. In our data set we include individuals who were first interviewed in 2004, 2005, 2006, and re-interviewed in subsequent years. Thus, our final sample includes individuals who were followed over two, three, or four consecutive years. Weights are provided by the Italian National Institute of Statistics to correct the biases that may derive from this complex sampling scheme and from non response. 
In order to investigate the relation between the couples' labour market participation and their reproductive outcome, we consider all childless ${ }^{6}$ women who, at each EU-SILC wave, were aged 16-49 and living with a partner. These 832 women did or did not first become mothers in the twelve months following the survey. In total we observe 204 first births in the period, with an overall probability of giving birth to a first child in any one of the following years of about $24.5 \%$. Our sample is small, but it gives us the possibility of monitoring the economic situation (employment status and earnings) of both partners at the same time in very recent years.

We do not adopt an event-history approach here (like, e.g., Santarelli 2011) because we observe our childless couples only for a short time period (one to three years). With logistic regression, we estimate the probability of having a first child in a given year according to the women's (and partners') characteristics in the preceding year. Women drop out of the sample if they have a (first) child; if not they are considered also for the following year. Each additional year is considered an independent observation, but the standard errors are adjusted for the possible intragroup correlations. For our analyses we use a set of twelve independent variables (see Appendix), reflecting the situation at the beginning of the period of observation. All our variables also include missing categories.

The age of the woman is coded into five categories: up to 24, 25-29, 30-34, 35-39, and $40+$. The household composition is reflected by an indicator measuring whether the respondent is married to, or simply living together with, a partner. We cannot account for couples' union duration because this information is not available in EUSILC data. The respondent's and the partner's education are grouped into three categories, consistent with the International Standard Classification of Education (ISCED). The lowest category corresponds to lower secondary school, primary school, or lower education. In the intermediate level we find people who received upper secondary education or post-secondary, but non-tertiary, education. Individuals with tertiary education are assigned to the highest category. The region of residence is broken down into three categories: Northern, Central, and Southern Italy (including the Islands).

The respondent's and the partner's economic conditions are described through six variables, reflecting their income in the reference period (January 1st to December 31st of the preceding year). The indicator used for individual income is the sum of various types of income sources, such as employee cash income, non cash income (e.g., company car and associated costs, free or subsidised meals), and social transfers. The indicator does not include income from capital investments, such as interest and

\footnotetext{
${ }^{6}$ Note that there are no retrospective questions on motherhood in our data: we classify all women with no (own) children in the household as childless. We therefore introduce a potential bias: women whose first child either died or left the parental home before the survey are wrongly classified as childless and included in the analysis. Given the relatively young age of the women in our sample (16 to 49) and the context (very low infant and child mortality; late fertility and late exit from the parental home) this bias is very likely negligible.
} 
dividends. The main activity status indicates whether an individual is working or not. Those who did not work are divided between those who report themselves as unemployed or not active/still in education. Information on the type of contract is coded into three categories: work contract of unlimited duration, work contract of limited duration (of unspecified length), and all others. The self-employed are classified as having a work contract of unlimited duration. All the economic variables are available separately for the respondent and the partner/spouse.

\section{Results}

Table 1 displays the results of our models. In Model 1 (M1) we investigate the direction of the income effect of the respondent and her husband or partner, controlling for the respondent's age, household composition, and region of residence. The results show a strong positive effect of the partner's income: the higher the income, the higher the Odds Ratio (OR) of having a first child in the next year. The OR for men with high income as compared to men with low income is 2.56 , and the difference is highly statistically significant. As for women's income, the effect is less clear, and not statistically significant. A U-shaped relation seems to emerge, though: women with medium income tend to have lower fertility than others, with high or low income. Overall these outcomes corroborate the traditional microeconomic interpretation that emphasizes the male partner's breadwinner role in Italy.

The age of the respondent acts in the expected direction: the risk of having a first child is highest in the reference group (25-29), and lower before and after that. The results for the variable 'household composition' confirm the common finding that fertility is (much) higher for married than for cohabiting women. We also find that the risk of having a first birth remains higher in the southern part of Italy when controlling for income, household composition, and age.

In Model 2 (M2) we additionally include the highest level of education achieved by the woman and her spouse or partner. Partners of higher education are more likely to have a first child in the observed period. Interestingly, although not statistically significant, these findings confirm a recent trend observed in Italy, which indicates that couples with greater cultural and economic resources do not have a lower fertility than others (Dalla Zuanna and Tanturri 2007; Rosina and Testa 2009). Since income and education are positively correlated, controlling for education absorbs part of the income effect of the previous model; however, for men, a higher income is still significantly correlated with a higher OR of having a first child.

In Model 3 (M3) we add information on economic stability, represented by the labour market situation of both partners. The chance of having a child in the next year is 
higher for non active women than for their employed counterparts, although not significantly. The pattern for men tends to be the opposite, although, once again, the difference is not significant, as the number of non employed men is very small (see Table A1, Appendix). Holding a permanent rather than a temporary job contract increases the chances of having a first child, for both partners. In other words, for employed individuals, a work contract of limited duration is significantly associated with a lower fertility risk; for men only slightly more than for women. Adjusting for the labour market situation of both couple members reduces the income effect for men somewhat, but it remains statistically significant.

Table 1: Odds ratios for having a first child in Italy. 2004-2007

\begin{tabular}{|c|c|c|c|c|c|c|}
\hline & \multicolumn{2}{|c|}{ Model 1} & \multicolumn{2}{|c|}{ Model 2} & \multicolumn{2}{|c|}{ Model 3} \\
\hline & OR & SE & OR & SE & OR & SE \\
\hline \multicolumn{7}{|c|}{ Age of Woman (Ref $=25-29)$} \\
\hline up to 24 & 0.88 & 0.40 & 0.90 & 0.42 & 0.97 & 0.47 \\
\hline $30-34$ & 0.79 & 0.19 & 0.76 & 0.18 & 0.74 & 0.18 \\
\hline $35-39$ & $0.33^{* * *}$ & 0.10 & $0.32^{* * *}$ & 0.10 & $0.32^{* * *}$ & 0.10 \\
\hline 40 and older & $0.15^{* * *}$ & 0.08 & $0.15^{* * *}$ & 0.08 & $0.14^{* * *}$ & 0.08 \\
\hline \multicolumn{7}{|c|}{ Household Compositon (Ref $=$ Married) } \\
\hline Partnership & $0.28^{* * *}$ & 0.08 & $0.29 * * *$ & 0.09 & $0.31^{* * *}$ & 0.09 \\
\hline \multicolumn{7}{|c|}{ Region (Ref = North) } \\
\hline Center & 0.93 & 0.22 & 0.93 & 0.23 & 0.92 & 0.23 \\
\hline South + Islands & $1.75^{* *}$ & 0.48 & $1.74^{* *}$ & 0.47 & $1.95^{* *}$ & 0.56 \\
\hline \multicolumn{7}{|c|}{ Income Tercile Woman $($ Ref = Low) } \\
\hline Medium & 0.89 & 0.22 & 0.89 & 0.22 & 1.15 & 0.36 \\
\hline High & 1.34 & 0.34 & 1.27 & 0.34 & 1.64 & 0.56 \\
\hline \multicolumn{7}{|c|}{ Income Tercile Man (Ref = Low) } \\
\hline Medium & $1.92 * *$ & 0.51 & $1.83^{* *}$ & 0.49 & $1.61^{*}$ & 0.46 \\
\hline High & $2.56^{\star * *}$ & 0.74 & $2.34^{* * *}$ & 0.68 & $2.07^{* *}$ & 0.62 \\
\hline \multicolumn{7}{|c|}{ Education Woman (Ref = Low) } \\
\hline Medium & & & 1.21 & 0.35 & 1.27 & 0.34 \\
\hline High & & & 1.31 & 0.45 & 1.38 & 0.48 \\
\hline \multicolumn{7}{|c|}{ Education Man $($ Ref = Low) } \\
\hline Medium & & & 0.95 & 0.21 & 0.86 & 0.20 \\
\hline High & & & 1.29 & 0.44 & 1.15 & 0.40 \\
\hline \multicolumn{7}{|c|}{ Activity Status Woman (Ref $=$ Working) } \\
\hline Unemployed & & & & & 1.06 & 0.47 \\
\hline Not active & & & & & 1.66 & 0.56 \\
\hline
\end{tabular}


Table 1: (Continued)

\begin{tabular}{|c|c|c|c|c|c|c|}
\hline & \multicolumn{2}{|c|}{ Model 1} & \multicolumn{2}{|c|}{ Model 2} & \multicolumn{2}{|c|}{ Model 3} \\
\hline & OR & SE & OR & SE & OR & SE \\
\hline \multicolumn{7}{|c|}{ Activity Status Man (Ref = Working) } \\
\hline Unemployed & & & & & 0.50 & 0.32 \\
\hline Not active & & & & & 0.54 & 0.32 \\
\hline \multicolumn{7}{|c|}{ Duration Contract Woman (Ref $=$ Permanent) } \\
\hline Temporary & & & & & 0.50 * & 0.21 \\
\hline \multicolumn{7}{|c|}{ Duration Contract Man (Ref $=$ Permanent) } \\
\hline Temporary & & & & & 0.46 * & 0.22 \\
\hline
\end{tabular}

Notes: ${ }^{*} \mathrm{p}<.1,{ }^{* *} \mathrm{p}<.05,{ }^{* * *} \mathrm{p}<.01$; Models also include missing categories; Models are adjusted for intra-group correlations

In the next interaction model between gender and duration of work contract (M4, Table 2) we investigate the gendered effect of the employment situation of both partners in more detail. The results suggest that fertility is lowest when the man has a contract of limited duration and the woman has a permanent contract. For these couples the OR of having a first child is only about one-sixth as compared to couples where both partners have a permanent job, and the difference is statistically significant. A significantly lower fertility risk can also be found for the couples in the opposite situation (women with temporary contract and men with permanent contract). Note that when the woman is temporarily employed and the male partner is permanently employed the likelihood of having a child is higher than when she is stable and he is instable in the labour market. Male unemployment reduces fertility (not significantly, though), but female unemployment does not. Overall, again, these findings tend to suggest the crucial role on fertility played by the economic standing of the man in Italy and they suggest that fertility may decline further, if the general performance of men as breadwinners erodes.

Table 2: Combination between gender and duration of contract

\begin{tabular}{lccc}
\hline \multicolumn{1}{c}{$\begin{array}{c}\text { Model 4 } \\
\text { Man }\end{array}$} & Permanent Contract & $\begin{array}{c}\text { Woman } \\
\text { Temporary Contract }\end{array}$ & Unemployed \\
\hline Permanent Contract & 1 & $0.38^{* *}$ & 1.07 \\
Temporary Contract & $0.16^{* *}$ & - & - \\
Unemployed & 0.44 & - & - \\
\hline
\end{tabular}

Notes: ${ }^{* \star} p<.05$; Additionally controlled for Age at interview, Household composition, region, income woman, income man, education woman, education man, and status as nonactive; Values are missing when the number of observations is too small (<=15); Model is adjusted for intra-group correlations 


\section{Conclusions}

Although presented as the remedy against economic problems and unemployment since the 1990s, the expansion of temporary job contracts has raised concern that these jobs may constitute an additional source of insecurity and precariousness for young workers and their families. According to the Stiglitz Commission (2009, p. 198), "Economic insecurity may be defined as uncertainty about the material conditions that may prevail in the future. This insecurity may generate stress and anxiety in the people concerned." In Italy, there is a vast amount of research on the possible negative consequences of atypical employment for the workers' economic situation and for future occupational and career prospects (e.g., Scherer 2004; Cutuli 2008; Barbieri, Scherer 2009). Much less is known about its possible social and demographic consequences, like family formation (Esping-Andersen 2007). In our study we focused on this knowledge-gap by examining the effect of job insecurity - in terms of type of contracts within the couple on first child fertility differentials in contemporary Italy. Our results, albeit limited by the small number of cases in our sample, indicate that individuals make their procreative choices keeping in mind their economic situation and perspectives.

Higher income of both couple members is related to an increase in the likelihood of having the first child. The impact of the man's income is much stronger, however, and remains important after adjusting for activity status and duration of the work contract. This result confirms that the economic well-being of the household, which still depends chiefly on the economic situation of the man, is crucial for the decision to have the first child. More generally, Italy finds itself in a mixed situation: here couples are neither fully traditional nor entirely modern. The "first pillar" (i.e., a male partner with a well-paid job) is still crucial in determining fertility decisions, probably because it gives the household a feeling of (relative) economic security. But this "old" family typology is becoming less prevalent. Increasingly, both partners are employed, and in this case the characteristics of their employment prove important. A permanent occupation for both partners is associated with higher fertility, while alternative job typologies for either of the two depress fertility.

This leads us to conjecture that the degree of job stability may be an important predictor of the onset of the fertility process. The very low level of fertility in Italy has been imputed to a number of factors, including the southern European welfare regime (Reher 1998; Esping-Andersen 1999), "familism" (Dalla Zuanna 2001), low levels of state support for child care (Pinnelli 1995), difficulties faced by women in balancing work and family life (Salvini 2004), etc. All this may be true, but we suggest that another element is worth considering: the increasing economic uncertainty of young Italian couples. Until the general economic situation improves, in this respect, our results suggest that the prospects for a fertility recovery remain critical. 
The implications of our findings should not be overstated: our period of observation is short, our sample is small, and left censoring may introduce bias in the couples that we observe. But our study presents, at the least, a hypothesis for future research because job insecurity (and economic uncertainty more generally) has become an issue in Italy. Not only in economic but also in demographic terms, because it has now been established as one of the factors associated with low fertility. Further studies will need to confirm our findings.

\section{Acknowledgements}

We thank Gunnar Andersson, Gerda Neyer, and two anonymous referees for their comments. We are also grateful to Davide di Laurea (Italian National Institute of Statistics - ISTAT) for his advice on the weighting procedure and Eleonora Mussino for her help with EU-SILC data. 


\section{References}

Adserà, A. (2005). Vanishing children: From high unemployment to low fertility in developed countries. American Economic Review 95(2): 189-193. doi: $10.1257 / 000282805774669763$.

Ahn, N. and Mira, P. (2002). A note on the changing relationship between fertility and female employment rates in developed countries. Journal of Population Economics 15(4): 667-682. doi:10.1007/s001480100078.

Baizan, P. (2005). Couples' career and fertility. An event history analysis of the ECHP samples of Denmark, Italy, Spain and United Kingdom. Paper presented at the XXV International Population Conference, Tours, France, July 18-23, 2005.

Barbieri, P. (2011). Italy: No country for young men (and women). In: Buchholz, S. and Hofäcker, D. (eds.). The flexibilization of European labor markets: The development of social inequalities in an era of globalization. Cheltenham, UK/Northampton, MA: Edward Elgar.

Barbieri, P. and Bozzon, R. (2009). Labor market and fertility decisions in the 'Latin model'. Paper presented at the QMSS II Conference "Advances in Family and Fertility Research", Groningen, Netherlands, October 15-16 2009.

Barbieri, P. and Scherer, S. (2009). Labour market flexibilisation and its consequences in Italy. European Sociological Review 25(6): 677-692. doi:10.1093/esr/jcp009.

Becker, G. (1981). A treatise on the family. Cambridge, USA: Harvard University Press.

Bernardi, F. and Nazio, T. (2005). Globalization and the transition to adulthood in Italy. In: Blossfeld, H.-P., Klijzing, E., Mills, M., and Kurz, K. (eds.). Globalization, uncertainty and youth in society. London: Routledge: 349-374.

Bettio, F. and Villa, P. (1998). A Mediterranean perspective on the breakdown of the relationship between participation and fertility. Cambridge Journal of Economics 22(2): 137-171.

Billari, F. (2005). The transition to parenthood in European societies. In: Hantrais, L., Philipov, D., and Billari, F.C. (eds.). Policy implications of changing family formation, Population Studies 49. Strasbourg: Council of Europe Publishing: 63116.

Blossfeld, H.-P. (ed.) (1995). The new role of women. Family formation in modern societies. Boulder: Westview Press. 
Blossfeld, H.-P., Klizing, E., Mills, M., and Kurz, K. (eds.) (2005). Globalization, uncertainty and youth in society. London and New York: Routledge.

Brewster, K.L. and Rindfuss, R.R. (2000). Fertility and women's employment in industrialized nations. Annual Review of Sociology 26(1): 271-296. doi:10.1146/annurev.soc.26.1.271.

Corijn, M., Liefbroer, A.C., and Gierveld, J.D. (1996). It takes two to tango, doesn't it? The influence of couple characteristics on the timing of the birth of the first child. Journal of Marriage and the Family 58(1): 117-126. doi:10.2307/353381.

Cutuli, G. (2008). Lavoro atipico e salari: Una discriminazione nascosta nel mercato del lavoro Italiano. Polis: Ricerche e studi su società e politica in Italia 3: 403-422. doi:10.1424/28283.

Dalla Zuanna, G. (2001). The banquet of Aeolus: A familistic interpretation of Italy's lowest low fertility. Demographic Research 4(5): 133-162. doi:10.4054/ DemRes.2001.4.5.

Dalla Zuanna, G. and Tanturri, M.L. (2007). Veneti che cambiano 1971-2021. La popolazione sotto la lente di quattro censimenti. Verona: Edizioni CIERRE.

De la Rica, S. and Iza, A. (2005). Career planning in Spain: Do fixed-term contracts delay marriage and parenthood? Review of Economics of the Household 3(1): 49-73. doi:10.1007/s11150-004-0979-8.

Drew, E., Emerek, R., and Mahon, E. (eds.) (1998). Women, work and the family in Europe. London: Routledge.

Engelhardt, H., Kögel, T., and Prskawetz, A. (2004). Fertility and women's employment reconsidered: A macro-level time-series analysis for developed countries, 19602000. Population Studies 58(1): 109-120. doi:10.1080/0032472032000167715.

Esping-Andersen, G. (1999). Social foundations of postindustrial economies. Oxford: Oxford University Press.

Esping-Andersen, G. (ed.) (2007). Family formation and family dilemmas in contemporary Europe. Bilbao: Fundacion BBVA.

European Commission (2010). Eurostat Home [electronic resource]. http://www.epp. eurostat.ec.europa.eu.

Eurostat New Cronos Database [electronic resource]. http://www.ec.europa.eu/eurostat.

Ferrera, M. (1985). Il welfare state in Italia. Sviluppo e crisi in prospettiva comparata. Bologna: Il Mulino. 
Ferrera, M. (1996). The Southern model of welfare in social Europe. Journal of European Social Policy 6(1): 17-37. doi:10.1177/095892879600600102.

Ferrera, M. (2000). Reconstructing the welfare state in Southern Europe. In: Kuhnle, S. (ed.). Survival of the European welfare state. London: Routledge: 166-181.

Goldstein, J.R., Sobotka, T., and Jasilioniene, A. (2009). The end of "lowest-low" fertility? Population and Development Review 35(4): 663-699. doi:10.1111/ j.1728-4457.2009.00304.x.

Gonzalez, M.J. and Jurado-Guerrero, T. (2006). Remaining childless in affluent economies: A comparison of France, West Germany, Italy and Spain, 19942001. European Journal of Population 22(4): 317-352. doi:10.1007/s10680006-9000-y.

Hoem, B. (2000). Entry into motherhood in Sweden: The influence of economic factors on the rise and fall in fertility, 1986-1997. Demographic Research 2(4). doi:10. 4054/DemRes.2000.2.4.

Hondroyiannis, G. (2010). Fertility determinants and economic uncertainty: An assessment using European panel data. Journal of Family and Economic Issues 31(1): 33-50. doi:10.1007/s10834-009-9178-3.

Istat (2011). Noi Italia [electronic-resource]. http://noi-italia.istat.it.

Kögel, T. (2004). Did the association between fertility and female employment within OECD countries really change its sign? Journal of Population Economic 17(1): 45-65. doi:10.1007/s00148-003-0180-z.

Kögel, T. (2006). An explanation of the positive correlation between fertility and female employment across Western European countries. Paper presented at the European Population Conference, Liverpool, United Kingdom, June 2006.

Kohler, H.-P. and Kohler, I. (2002). Fertility decline in Russia in the early and mid 1990s: The role of economic uncertainty and labour market crises. European Journal of Population 18(3): 233-262. doi:10.1023/A:1019701812709.

Kravdal, Ø. (2002). The impact of individual and aggregate unemployment on fertility in Norway. Demographic Research 6(10): 263-294. doi:10.4054/ DemRes.2002.6.10.

Kreyenfeld, M. (2010). Uncertainties in female employment careers and the postponement of parenthood in Germany. European Sociological Review 26(3): 351-366. doi:10.1093/esr/jcp026. 
Kreyenfeld, M. and Konietzka, D. (2005). Economic uncertainty and fertility - Evidence from German panel data. Paper presented at the XXV International Population Conference, Tours, France, July 18-23, 2005.

Matysiak, A. and Kotowska, I.E. (2011). How does employment uncertainty affect fertility? Evidence from Poland. Recwowe report, Task T02.22 "Fertility, female employment and reconciliation policies".

Matysiak, A. and Vignoli, D. (2008). Fertility and women's employment. A metaanalysis. European Journal of Population 24(4): 363-384. doi:10.1007/s10680007-9146-2.

Matysiak, A. and Vignoli, D. (2010). Employment around first birth in two adverse institutional settings: Evidence from Italy and Poland. Journal of Family Research 22(3): 331-346.

McDonald, P. (2000). Gender equity, social institutions and the future of fertility. Journal of Population Research 17(1): 1-16. doi:10.1007/BF03029445.

McDonald, P. (2002). Sustaining fertility through public policy: The range of options. Population 57(3): 417-446. doi:10.2307/3246634.

McDonald, P. (2006). Low fertility and the state: The efficacy of policy. Population and Development Review 32(3): 485-510. doi:10.1111/j.1728-4457.2006.001 34.x.

Mencarini, L. (2006). Il secondo figlio. In: Rosina, A. and Sabbadini, LL. (eds.). Diventare padri in Italia. Fecondità e figli secondo un approccio di genere. Rome: Istat: 109-128.

Mencarini L. and Solera, C. (2011). Percorsi verso la vita adulta tra lavoro e famiglia: differenze di genere, istruzione e coorte. In: Sartor, N., Schizzerotto, A., and Trivellato, U. (eds.). Generazioni diseguali. Le condizioni di vita dei giovani di ieri e di oggi: un confronto. Bologna: Il Mulino: 175-209.

Mills, M. and Blossfeld, H.-P. (2005). Globalization, uncertainty and the early life course: A theoretical framework. In: Blossfeld, H.-P., Klijzing, E., Mills, M., and Kurz, K. (eds.). Globalization, uncertainty and youth in society. London and New York: Routledge: 1-24.

Neyer, G., Lappegård, T., and Vignoli, D. (2011). Gender equality and fertility: Which equality matters? Stockholm: Stockholm University Linnaeus Center on Social Policy and Family Dynamics in Europe, SpaDE (SRRD_2011:9) and Florence: University of Florence, Department of Statistics (WP 2011/07). 
Ongaro, F. (2002). Low fertility in Italy between explanatory factors and social and economic implications: Consequences for the research. In: Proceedings XLI Riunione Scientifica della SIS. Padua: CLEUP. (June, 5-7, Sessioni plenarie e specializzate).

Oppenheimer, V.K. (1976). The Easterlin hypothesis: Another aspect of the echo to consider. Population and Development Review 2(3/4): 433-475. doi:10.2307/ 1971621.

Oppenheimer, V.K. (1988). A theory of marriage timing. American Journal of Sociology 94(3): 563-591. doi:10.1086/229030.

Oppenheimer, V.K. (2003). Cohabiting and marriage during young men's careerdevelopment process. Demography 40(1): 127-149. doi:10.2307/3180815.

Pailhé, A. and Solaz, A. (2008). Time with children: Do fathers and mothers replace each other when one parent is unemployed? European Journal of Population 24(2): 211-236. doi:10.1007/s10680-007-9143-5.

Pinnelli, A. (1995). Women's condition, low fertility, and emerging union patterns in Europe. In: Mason, K.O. and Jensen, A.M. (eds.). Gender and family change in industrialized countries. Oxford: Clarendon Press.

Pinnelli, A. and Di Giulio, P. (2003). Genere e determinanti della fecondità nei paesi sviluppati. In: Pinnelli, A., Racioppi, F., and Rettaroli, R. (eds.). Genere e Demografia. Bologna: Il Mulino.

Reher, D.S. (1998). Family ties in Western Europe: Persistent contrasts. Population and Development Review 24(2): 203-234. doi:10.2307/2807972.

Rosina, A. and Fraboni, R. (2006). Il primo figlio. In: Rosina, A. and Sabbadini, L.L. (eds.). Diventare padri in Italia. Fecondità e figli secondo un approccio di genere. Rome: Istat: 87-108.

Rosina, A. and Sabbadini, L.L. (2006). Introduzione. In: Rosina, A. and Sabbadini, L.L. (eds.). Diventare padri in Italia. Fecondità e figli secondo un approccio di genere. Rome: Istat: 11-22.

Rosina, A. and Testa, M.R. (2009). Couples' first child intentions and disagreement: An analysis of the Italian case. European Journal of Population 25(4): 487-502. doi:10.1007/s10680-009-9188-8.

Salvini, S. (2004). Low Italian fertility: The Bonaccia of Antilles? Genus LX(1): 19-38. 
Salvini, S. and Ferro, I. (2007). Young workers and flexibility of the labour market: What family strategies? Florence: University of Florence, Department of Statistics (WP 2007/13).

Santarelli, E. (2011). Economic resources and the first child in Italy: A focus on income and job stability. Demographic Research 25(9): 311-336. doi:10.4054/ DemRes.2011.25.9.

Scherer, S. (2004). Stepping-stones or traps? The consequences of labour market entry position for the further career chances in Germany, Italy and Great Britain. Work, Employment and Society 18(2): 369-394. doi:10.1177/09500172 004042774 .

Scherer, S. (2009). The social consequences of insecure jobs. Social Indicators Research 93(3): 527-547. doi:10.1007/s11205-008-9431-4.

Singley, S.G. and Hynes, K. (2005). Transitions to parenthood. Work-family policies, gender, and the couple context. Gender and Society 19(3): 376-397. doi:10.1177/0891243204271515.

Sobotka, T., Skirbekk, V., and Philipov, D. (2011). Economic recession and fertility in the developed world. Population and Development Review 37(2): 267-306. doi:10.1111/j.1728-4457.2011.00411.x.

Stiglitz, J.E., Sen, A., and Fitoussi, J.-P. (2009). Report by the Commission on the Measurement of Economic Performance and Social Progress. http://www.stiglitz-sen-fitoussi.fr.

Vignoli, D. and Salvini, S. (2008). Employment and fertility careers in Italy: The gender-specific effect within couples. Paper presented at the Annual Conference of the Population Association of America, New Orleans, United States, April 1719, 2008. 


\section{Appendix}

Table A1: Distribution of observations by categories of each variable

\begin{tabular}{|c|c|c|}
\hline & & $\begin{array}{c}\text { Distribution } \\
\%\end{array}$ \\
\hline \multirow[t]{5}{*}{ Age of Woman } & up to 24 & 7.8 \\
\hline & $25-29$ & 25.7 \\
\hline & $30-34$ & 31.4 \\
\hline & $35-39$ & 24.6 \\
\hline & 40 and older & 10.5 \\
\hline \multirow[t]{2}{*}{ Household Composition } & Partnership & 22.2 \\
\hline & Married & 77.8 \\
\hline \multirow[t]{3}{*}{ Region of Residence } & North & 58.2 \\
\hline & Center & 18.1 \\
\hline & South + Islands & 23.8 \\
\hline \multirow[t]{3}{*}{ Income Tercile Woman } & Low & 33.5 \\
\hline & Medium & 33.5 \\
\hline & High & 33.0 \\
\hline \multirow[t]{3}{*}{ Income Partner/Spouse } & Low & 33.5 \\
\hline & Medium & 33.3 \\
\hline & High & 33.2 \\
\hline \multirow[t]{3}{*}{ Education Woman } & Low & 27.8 \\
\hline & Medium & 50.1 \\
\hline & High & 22.1 \\
\hline
\end{tabular}


Vignoli, Drefahl \& De Santis: Job instability and parenthood in Italy

Table A1: (Continued)

\begin{tabular}{llr}
\hline & & Distribution \\
Education Partner/Spouse & Low & 36.8 \\
& Hedium & 49.4 \\
& Unknown & 13.2 \\
& & 0.6 \\
Activity Status Woman & Working & \\
& Unemployed & 73.6 \\
Activity Status Partner/Spouse & Not active & 9.5 \\
& & 16.9 \\
& Working & \\
& Unemployed & 92.0 \\
& Not active & 3.3 \\
Duration Contract Woman & & 4.7 \\
& Permanent & 61.2 \\
& Temporary & 11.4 \\
& Unknown / Missing & 27.3 \\
& & \\
Duration Contract Partner/Spouse & Permanent & 84.4 \\
& Temporary & 6.3 \\
& Unknown / Missing & 9.4 \\
\hline
\end{tabular}

Note: Totals may not always sum up to 100 due to rounding 